\title{
Clinical, Electrophysiological, Radiological Features and Prognosis of Creutzfeldt - Jakob Disease
}

\author{
Creutzfeldt-Jacob Hastalığının Klinik, Elektrofizyolojik \\ Özellikleri ve Prognozu
}

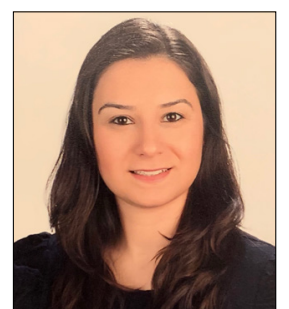

Dr. Fulya EREN

\author{
(1) Fulya EREN, \Sena GÜLER, (1) Günay GÜL, @ Ayten CEYHAN DíRICAN,

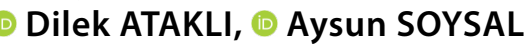

Department of Neurology, Bakırköy Prof. Dr. Mazhar Osman Training and Research Hospital for Neuropsychiatry, İstanbul, Turkey

\begin{abstract}
Summary
Objectives: Creutzfeldt- Jakob Disease (CJD) is a neurodegenerative disease characterized by abnormally-shaped proteins. CJD is the most common type of prion diseases with incidence of $1 / 100000$ per year. In this study, we aimed to review clinical, laboratory, electrophysiological and radiological findings and prognosis of 21 cases with the diagnosis of CJD.

Methods: A retrospective review of patient records in a single institution was performed to identify patients with sporadic CJD from 2010 to 2018. January 2017 diagnostic criteria were used for inclusion. In this study, 21 patients were included for analysis. Demographic features, symptoms, clinical findings of neurological examination, disease duration, laboratory findings, electrophysiological test results, findings of magnetic resonance imaging and prognosis were documented.

Results: Twelve of the patients included in this study were male and nine were female. The mean age was 64.1 (49-79). All the patients had dementia and changes in personality at admission to the hospital. The duration of complaints was $5.4 \pm 4$ months. Periodic sharp wave complexes were observed in the electroencephalogram at baseline or follow-up. Twenty patients had undergone lumbar puncture to identify 14.3.3 protein tests in cerebrospinal fluid. In six of twelve patients whose results were received, 14.3.3 protein level was positive, whereas four of them were negative and two were at borderline. Seven patients died of the disease during the follow-up in our hospital within 2.8 (1-6) months from the symptom onset.
\end{abstract}

Conclusion: In patients with rapidly progressive dementia, behavioral changes, hallucinations and myoclonus, CJD should be kept in mind for earlier diagnosis.

Keywords: Creutzfeldt-Jacob disease; dementia; neurodegenerative disease; prion.

\section{Özet}

Amaç: Creutzfeld Jacob hastalığı (CJH) hızlı ilerleyen demans, miyokloniler ile seyreden ve kısa sürede ölüm ile sonuçlanan nörodejeneratif bir hastalıktır. Bu çalışmada, oldukça nadir görülen bu hastalık tanısı ile takip edilen 21 olgunun klinik, laboratuvar, elektrofizyolojik ve radyolojik bulgularının gözden geçirilmesi amaçlanmıştır.

Gereç ve Yöntem: Hastanemiz nöroloji kliniklerinde 2010-2018 yılları arasında CJH tanısı ile yatarak takip edilmiş olan 21 hasta çalışmaya dahil edilmiştir. Hastaların demografik özellikleri, muayene bulguları, hastalık süresi, laboratuvar testleri, elektrofizyolojik ve radyolojik incelemeleri, prognozları geriye dönük olarak dökümente edilmiştir.

Bulgular: Hastaların 12'si erkek, dokuzu kadındı. Ortalama yaş 64.1 (49-79) olarak bulundu.Tüm hastalar hastaneye başvurduklarında demans ve kişilik değişikliğinden yakınmaktaydı. Şikayetlerin başlangıç süresi $5.4 \pm 4$ ay olarak bulundu. Başlangıçta ya da takiplerinde EEG'lerde periyodik keskin yavaş dalga kompleksleri tespit edildi. Yirmi hastaya beyin omurilik sıvısında (BOS) 14.3.3 proteini testi yapılması için lomber ponksiyon yapıldı. Sonuçlarına ulaşılan 12 hastanın altısında BOS'de 14.3.3 proteini pozitif, dördünde negatif, ikisinde de sınır değer olarak bulundu. Yedi hastanın hastanedeki takipleri sırasında, semptomların başlangıcından ortalama 2.8 (1-6) ay sonra öldüğü dökümente edildi.

Sonuç: Hızlı ilerleyen demans, davranış değişiklikleri, halusinasyonlar ve miyokloniler ile birlikte seyreden CJH, psikiyatrik ve nörolojik pek çok tablo ile ayırıcı tanıya girebildiğinden erken tanıda akılda tutulması gereken bir hastalıktır.

Anahtar sözcükler: Creutzfeldt-Jacob hastalığı; demans; nörodejeneratif hastalık; prion.

Submitted (Geliş): 10.03.2020

Accepted (Kabul) : 29.06.2020 


\section{Introduction}

Creutzfeldt- Jakob Disease (CJD) is a fatal neurodegenerative disease characterized by abnormally shaped proteins. ${ }^{[1]}$ CJD is the most common type of prion disease with the incidence of $1 / 100000$ per year. ${ }^{[2]}$

CJD can be classified into four main groups having heterogeneous phenotypes, epidemiologic features and pathologies: sporadic (sCJD), familial, iatrogenic and variant CJD (vCJD). ${ }^{[3]}$ The most frequent type is sporadic CJD, with $85-$ $95 \%$ of the patients. ${ }^{[3,4]}$

The disease is characterized by rapidly progressive dementia, behavioral abnormalities such as irritability, social withdrawal and judgment difficulties, visual disturbances, extrapyramidal signs and myoclonus. ${ }^{[4]}$ The diagnosis is based on clinical features, imaging, laboratory and electrophysiological tests. The definite diagnosis requires histopathological examination of brain tissue to show PrPSc deposition, nerve cell loss and gliosis, ${ }^{[1]}$ which can only be done by autopsy. Today, there is no known cure for the disease and almost always disease course is fatal. There are some treatment modalities to minimize symptoms like seizures, myoclonus,

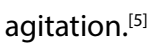

\section{Clinical rationale for this study}

Currently, there is no established treatment for CJD despite many ongoing studies. It is hard to diagnose CJD with its initial clinical findings. We believe the findings of this study on the clinical course of CJD will contribute to the literature and increase awareness of the disease, especially in the early stages. In this study, we aimed to review clinical, laboratory, electrophysiological and radiological findings and prognosis of 21 cases with the diagnosis of CJD.

\section{Materials and Methods}

A retrospective review of patient records in a single institution was performed to identify patients with sporadic CJD (sCJD) from 2010 to 2018. In this study, 21 patients were included for further analysis. 2018 amended diagnostic criteria were used for inclusion (Table 1) and all patients were diagnosed as probable sCJD. ${ }^{[6]}$

Demographic features, symptoms, clinical findings of neurological examination, duration of disease, laboratory findings, results of electrophysiological tests, radiological find- ings of magnetic resonance imaging (MRI) and prognosis were documented.

\section{Results}

Twelve of the patients included in this study were male and nine were female. The mean age was 64.1 (49-79). All the patients had dementia and changes in personality at admission to the hospital. The duration of complaints was $5.4 \pm 4$ months. Five patients had additional visual hallucinations.

During follow-up, it was observed that 13 patients had become bed dependent and 10 patients lost communication,

Table 1. Diagnostic criteria for sporadic CreutzfeldtJakob disease

\subsection{Definite}

Progressive neurological syndrome AND

Neuropathologically or immunohistochemically or biochemically confirmed

1.2 Probable

1.2.1 I + two of II and typical electroencephalogram

OR 1.2.2 I + two of II and typical magnetic resonance imaging brain scan

OR 1.2.3 I + two of II and positive cerebrospinal fluid (CSF) 14.3 .3

OR 1.2.4 Progressive neurological syndrome and positive real-time-quacking-induced conversion in CSF or other tissues

1.3 Possible I + two of II + duration $<2$ years

I Rapidly progressive cognitive impairment

II A Myoclonus

B Visual or cerebellar problems

C Pyramidal or extrapyramidal features

D Akinetic mutism

Table 2. A summary of clinical findings in our patient population

\begin{tabular}{lc}
\hline Clinical sign & Number of patients \\
\hline Dementia & 21 \\
Changes in personality & 21 \\
Myoclonus & 18 \\
Bed dependent & 13 \\
Akinetic mutism & 10 \\
Extrapyramidal system findings & 5 \\
Visual hallucinations & 5 \\
Cerebellar findings & 2 \\
Right hemiparesis & 1 \\
\hline
\end{tabular}



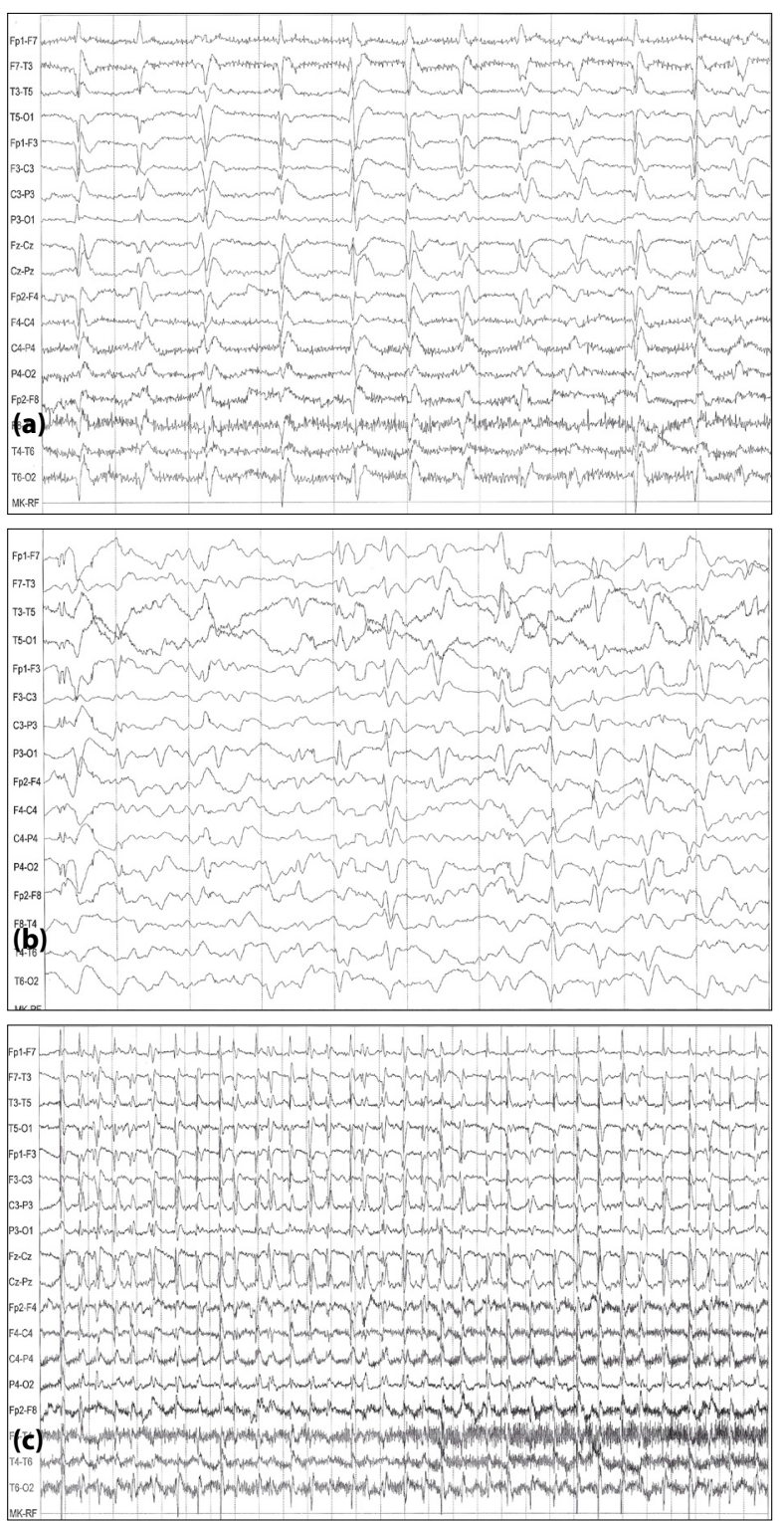

Fig. 1. (a) Scalp EEG of CJD patient in two months: PSWC 1-2/sec. (b) Scalp EEG of CJD patient in one month: Generalized triphasic sharp waves $1-2 /$ sec with slow background activity. (c) Scalp EEG of CJD patient in three months: Generalized periodic sharp-spike wave complexes with 30-second paper speed.

showing akinetic mutism. Extrapyramidal system findings were found in five patients, problems in cerebellar tests in two patients and right hemiparesis in one patient. Except for three patients, all patients had spontaneous or stimuli-induced myoclonus (Table 2).

In all patients, periodic sharp wave complexes were observed in the electroencephalogram (EEG) at baseline or
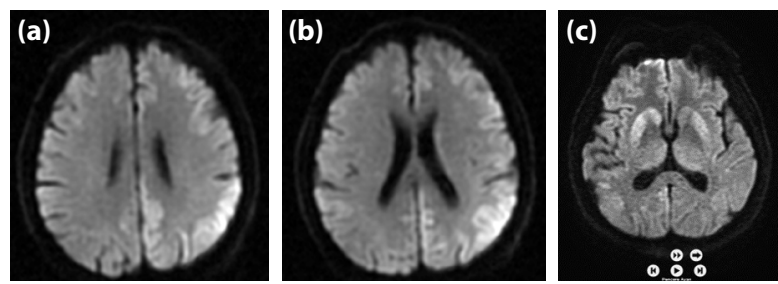

Fig. 2. (a, b) Cortical signaling in DWI (cortical ribboning). (c) Increased signal in caudate and putamen (hockey stick sign).

follow-up (Fig. 1a-c). Diffusion-weighted imaging (DWI) showed increased cortical signaling (cortical ribboning) consistent with SCJD. In addition, the cranial MRI of 4 patients showed increased signal in caudate and putamen 'hockey stick sign' (Fig. 2a-c).

Twenty patients underwent lumbar puncture to identify 14.3.3 protein tests in cerebrospinal fluid (CSF). In six of twelve patients whose results were received, 14.3 .3 protein level was positive, whereas four of them were negative and two were at borderline (Table 3).

Levetiracetam, valproic acid and clonazepam were used to control myoclonus. A combination of two antiepileptic drugs was tried in two patients.

Seven patients died of the disease during the follow-up in our hospital within 2.8 (1-6) months from the symptom onset; one patient was still under follow up. Unfortunately, medical records of remaining patients could not be reached for prognostic evaluation.

\section{Discussion}

CJD is a form of spongiform encephalopathies or prion diseases. PrPc is the normal protein, which is encoded by the prion gene (PRNP) and plays a role in many cellular processes. When misfolded, PrPsc is accumulated in brain tissue, causing neuronal degeneration, astrocytic gliosis and spongiform changes..$^{[2]}$

Table 3. Cerebrospinal fluid (CSF) 14.3.3 protein results in our patient population

\begin{tabular}{lc}
\hline CSF 14.3.3 results & Number of patients \\
\hline Unknown & 9 \\
+ & 6 \\
- & 4 \\
Borderline & 2 \\
\hline
\end{tabular}


CJD has its special triad as dementia, ataxia and myoclonus. Myoclonus may be caused by auditory and tactile stimuli or can be seen spontaneously. ${ }^{[7]}$ Hallucinations, cerebellar disturbances and behavioral changes are common findings. Toward the end stage of the disease, akinetic mutism is seen in many patients. Because CJD has different clinical manifestations, it is easily misdiagnosed as psychiatric diseases, metabolic or toxic diseases, Alzheimer's Disease (AD), frontotemporal dementia, central nervous system inflammation, tumor, stroke. ${ }^{[7,8]} \mathrm{CJD}$ has a rapid course causing death in six months. ${ }^{[2]}$ In our study, 18 patients had myoclonus, whereas 10 patients showed akinetic mutism.

Neuroimaging has an important role in diagnosis in both early detection of findings of CJD and differential diagnosis of CJD mimics. MRI shows hyperintensities in the bilateral cortex, basal ganglia and posterior thalamus in DWI. ${ }^{[4,9]}$ In later stages of the disease, generalized atrophy and ventricular dilatation are commonly seen ${ }^{[10,11]}$ The sensitivity of DWI and fluid-attenuated inversion recovery (FLAIR) imaging for early diagnosis is considered to be high, as $91 \%$ for sensitivity and $95 \%$ for specificity. ${ }^{[4,11]}$ Restricted diffusion on DWI sequence confirmed on apparent diffusion coefficient mapping may have specificity nearly $100 \%$, which makes DWI is the most efficient sequence of MRI in the diagnosis of sCJD. ${ }^{[12]}$ All patients in our study showed increased cortical signaling on DWI, inconsistent with the literature.

Periodic sharp-wave complexes (PSWC), which are symmetrical, generalized, triphasic, biphasic, or mixed complexes occurring approximately every second, are one of the main characteristic findings in Creutzfeldt-Jakob disease. ${ }^{[13]} \mathrm{EEG}$ has a specificity of $74-94 \%$ and a sensitivity of \%64-67 in sCJD [6]. In earlier stages of the disease, a generalized nonspecific diffuse slowing background may be the only finding on EEG. As the disease progresses, pathological findings, such as lateralized PSWCs, evolve three months after the first presentation and tend to disappear in terminal stages. ${ }^{[13,14]}$ Therefore, patients should be examined using control EEGs, if suspected, although the first EEG shows no PSWC at all. In our series, positive findings in EEG were found in all patients either at baseline or in follow-up studies. Myoclonus is not directly related to EEG findings. ${ }^{[15]}$ In our series, three patients had specific EEG abnormalities without myoclonus.

14-3-3 protein is normally expressed in brain tissue and takes a role in signal transduction and apoptosis. ${ }^{[16]}$ When a neuronal injury occurs, it can be detected in CSF. Thus, it can be considered as a marker of acute neuronal injury. The CSF analysis of 14-3-3 protein has a sensitivity of $92 \%$ and specificity of $86 \% .{ }^{[4]}$ Moreover, there are new studies on the combination of analysis of 14-3-3 protein with tau, showing increased specificity, especially in the differential diagnosis of CJD and $A D .{ }^{[8]}$ In our clinic, twenty patients underwent lumbar puncture and were tested for 14-3-3 protein. However, some of the results were lost to follow-up. In six of twelve patients, 14-3-3 protein levels were found to be positive. We have not observed a significant correlation between 14-3-3 positive patients and poor prognosis. Gushue et al. ${ }^{[17]}$ also studied this relationship and concluded that CSF 14-3-3 positivity did not affect prognosis in rats.

Real-time quaking-induced conversion (RT-QuIC) is a new and promising test with a sensitivity of $97 \%$ and specificity of $100 \%$ for diagnosing SCJD. ${ }^{[4,18]}$ The principle of RT-QuIC allows the antemortem diagnosis of SCJD. ${ }^{[17]}$ Because there is a need for specific serum biomarkers for $\mathrm{SCJD}$, neurofilament light chain and tau were investigated for this purpose; and found increased in serum of patients. The serum tau level was also found to be correlated with disease progression. ${ }^{[19]}$ Unfortunately, routine measurement of biomarkers is not possible in our country.

\section{Clinical implications/future directions}

Creutzfeldt-Jakob disease, which can be definitely diagnosed by pathological and histochemical examinations, is a very rare disease, arises from mutations in the prion protein. For diagnosis, specific clinical, laboratory, electrophysiological and radiological findings are required. Because findings in the prodromal period can be easily misdiagnosed as psychiatric diseases, the diagnosis is usually delayed. For this reason, in patients with rapidly progressive dementia, behavioral changes, hallucinations and myoclonus, CJD should be kept in mind for earlier diagnosis. It possible to conclude that there are several tests available for an accurate diagnosis, but we still lack reliable prognostic tools and effective treatment modalities.

\section{Compliance with ethical standards}

This is a retrospective study; ethical committee approval was not required.

All procedures performed in studies involving human participants were in accordance with the ethical standards of 
the institutional and/or national research committee and with the 1964 Helsinki declaration and its later amendments or comparable ethical standards.

\section{Peer-review}

Externally peer-reviewed.

\section{Conflict of interest}

The authors declare that they have no conflict of interest.

\section{Authorship Contributions}

Concept: F.E., A.S.; Design: F.E., G.G.; Supervision: A.S., D.A., G.G.; Materials: F.E., G.G.; Data collection \&/or processing: F.E., G.G.; Analysis and/or interpretation: F.E., G.G.; Literature search: F.E., S.G., A.C.D.; Writing: F.E., G.G., S.G.; Critical review: G.G., A.S., D.A.

\section{References}

1. Geschwind MD. Prion Diseases. Continuum (Minneap Minn) 2015;21 (6 Neuroinfectious Disease):1612-38. [CrossRef]

2. Mackenzie G, Will R. Creutzfeldt-Jakob disease: recent developments. F1000Res 2017;6:2053. [CrossRef]

3. Wang X, Li N, Liu A, Ma L, Shan P, Jiang W, et al. Three sporadic cases of Creutzfeldt-Jakob disease in China and their clinical analysis. Exp Ther Med 2017;14:2664-70. [CrossRef]

4. Tan B, Mangual CM, Mahmud I, Tongo ND, Mararenko L, Kay A. A Case Report of Probable Sporadic Creutzfeldt-Jakob Disease: How to Approach Early Diagnosis? Cureus 2017;9(5):e1297.

5. Appleby BS, Yobs DR. Symptomatic treatment, care, and support of CJD patients. Handb Clin Neurol 2018;153:399-408.

6. Hermann P, Laux M, Glatzel M, Matschke J, Knipper T, Goebel S, et al. Validation and utilization of amended diagnostic criteria in Creutzfeld-Jacob disease surveillance,Neurology, 2018;91(4): e331-e338. [CrossRef]

7. Aykac O, Arıca Polat BS, Erdoğan S, Sorgun MH, Delen F, Tuncay E, et al. Sporadik Creutzfeldt-Jacob Hastalığı: On Altı Hastanın Dökümü. Epilepsi 2016;22(2):46-50.

8. Dulamea A, Solomon E. Role of the biomarkers for the diagnosis of Creutzfeldt-Jakob disease. J Med Life 2016;9(2):211-5.

9. Fragoso DC, Gonçalves Filho AL, Pacheco FT, Barros BR, Aguiar Littig I, Nunes RH, et al. Imaging of Creutzfeldt-Jakob Disease:
Imaging Patterns and Their Differential Diagnosis. Radiographics 2017;37(1):234-57. [CrossRef]

10. Qavi AH, Imran TF, Hasan Z, llyas F, Ghani U, Assad S, et al. Serial Magnetic Resonance Imaging in Creutzfeldt-Jakob Disease: a Case Report and Literature Review. Cureus 2017;9(3):e1095.

11. Young GS, Geschwind MD, Fischbein NJ, Martindale JL, Henry RG, Liu $S$, et al. Diffusion-weighted and fluid-attenuated inversion recovery imaging in Creutzfeldt-Jakob disease: high sensitivity and specificity for diagnosis. AJNR Am J Neuroradiol 2005;26(6):1551-62.

12. Rudge $P$, Hyare $H$, Green $A$, Collinge J, Mead S. Imaging and CSF analyses effectively distinguish CJD from its mimics. J Neurol Neurosurg Psychiatry 2018;89(5):461-6. [CrossRef]

13. Isfahani SA, Dougherty M, Gliebus GP. Applicability of longterm electroencephalography in pre-mortem diagnosis of Creutzfeldt-Jakob disease: A case report. SAGE Open Medical Case Reports 2017;5:1-5. [CrossRef]

14. Ayyappan S, Seneviratne U. Electroencephalographic changes in sporadic Creutzfeldt-Jakob disease and correlation with clinical stages: a retrospective analysis. J Clin Neurophysiol 2014;31(6):586-93. [CrossRef]

15. Wieser HG, Schindler K, Zumsteg D. EEG in Creutzfeldt-Jakob disease. Clin Neurophysiol 2006;117(5):935-51. [CrossRef]

16. Peckeu L, Delasnerie-Lauprètre N, Brandel JP, Salomon D, Sazdovitch V, Laplanche JL, et al. Accuracy of diagnosis criteria in patients with suspected diagnosis of sporadic CreutzfeldtJakob disease and detection of 14-3-3 protein, France, 1992 to 2009. Euro Surveill 2017;22(41):16-00715. [CrossRef]

17. Gushue D, Herbst A, Sim V, McKenzie D, Aiken JM. 14-3-3 and enolase abundances in the CSF of Prion diseased rats. Prion 2018;12(3-4):253-60. [CrossRef]

18. Zanusso G, Monaco S, Pocchiari M, Caughey B. Advanced tests for early and accurate diagnosis of Creutzfeldt-Jakob disease. Nat Rev Neurol 2016;12(6):325-33. [CrossRef]

19. Thompson AGB, Luk C, Heslegrave AJ, Zetterberg $\mathrm{H}$, Mead SH, Collinge J, et al. Neurofilament light chain and tau concentrations are markedly increased in the serum of patients with sporadic Creutzfeldt-Jakob disease, and tau correlates with rate of disease progression. J Neurol Neurosurg Psychiatry 2018;89(9):955-61. [CrossRef] 